\title{
Potential of Okra (Abelmoschus esculentus L.) Extract to Reduce Blood Glucose and Malondialdehyde (MDA) Liver in Streptozotocin-Induced Diabetic Rats
}

\author{
Putri Puncak Anjani ${ }^{1 *}$, Evy Damayanthi ${ }^{1}$, Rimbawan ${ }^{1}$, Ekowati Handharyani ${ }^{2}$ \\ ${ }^{1}$ Department of Community Nutrition, Faculty of Human Ecology, Bogor Agricultural University, \\ Bogor 16680, Indonesia \\ ${ }^{2}$ Department Veterinary Clinic Reproduction and Pathology, Faculty of Veterinary Medicine, \\ Bogor Agricultural University, Bogor 16680, Indonesia
}

\begin{abstract}
The study aimed to analyze the potential of okra to reduction blood glucose and MDA liver in streptozotocin (STZ)-induced diabetic rats. Design experiment used in this study was pre and post test controlled group design. The first step of this study was analyzed bioactive compound of okra extract. The next step was administired orally of okra extract to control and diabetic rats induced by streptozotocin $50 \mathrm{mg} / \mathrm{kgBW}$ for 14 days. Sprague dawley rats were divided into six groups: normal control (N), diabetic control (DM), diabetic treated with green okra extract (GOE) with the dosage of $5 \mathrm{mg} / \mathrm{kgBW}$ quercetin and $10 \mathrm{mg} / \mathrm{kgBW}$ quercetin, diabetes treated with purple okra extract (POE) with the dosage of $5 \mathrm{mg} / \mathrm{kgBW}$ quercetin and $10 \mathrm{mg} / \mathrm{kgBW}$ quercetin. Blood glucose were measured each five days and malondialdehyde (MDA) liver in rats were measured in the end of intervention. The following results show that phenolic and quercetin of purple okra extract were higher $(3.60 \% ; 0.45 \mathrm{mg} / \mathrm{g})$ than green okra extract $(3.58 \% ; 0.27 \mathrm{mg} / \mathrm{g})$. Administration of GOE I, GOE II, POE I and POE II in diabetic rats showed significant $(\mathrm{P}<0.05)$ reduction in blood glucose level $(115.25 \mathrm{mg} / \mathrm{dl} ; 86 \mathrm{mg} / \mathrm{dl} ; 180.75 \mathrm{mg} / \mathrm{dl} ; 91 \mathrm{mg} / \mathrm{dl})$ and improve level of MDA. These results suggest that intervention of okra extract based on quercetin compound show an antihyperglicemic potential and improve MDA level.
\end{abstract}

Keywords: blood glucose, diabetic rats, malondialdehyde, okra extract, streptozotocin

\section{INTRODUCTION}

Diabetes mellitus (DM) is a chronic metabolic disease resulting in an impaired metabolism of carbohydrate, protein and lipid which associated with insufficient seceretion of insulin that occurs in type $1 \mathrm{DM}$ or increased insulin resistance as characterictic of type 2 DM (ADA 2014). Type $2 \mathrm{DM}$ represents more than $90 \%$ of all cases of $\mathrm{DM}$ in the world. According to the International Diabetes Federation (IDF), the number of diabetics reach 382 million in 2013 and this value is predicted to rise to around 592 million by 2035 (IDF 2013).

Hyperglycemia condition can increase oxidative stress by increasing the production of Reactive oxygen species (ROS) by electron transport chains in mitochondria characterized by the changes in glucose biochemistry and end-product of lipid peroxidation indicator i.e malondialdehyde (MDA) ( Gupta et al. 2009; Aouacheri et al.
2014). Increasing oxidative stress be risk factor leads to insulin resistance, dyslipidemia, $\beta$ cell dysfunction, impaired glucose tolerance and type 2 DM (Tangvarasittichai 2015).

Epidemiological studies suggested that consumption of foods rich in bioactive compounds as catechin in tea, anthocyanin in plants colored red, purple, blue, and quercetin compound can reduce risk of diabetes, heart disease, obesity, hyperlipidemia, stroke and cancer (Xiao et al. 2011; Wedick et al. 2012; Damayanthi et al. 2013). Okra (Abelmoschus esculentus L.) also known as lady finger or gumbo, is a tropical vegetable that included in the Mallow family. Okra contains of many flavonoids compounds which have antioxidant activity (Liao et al. 2012; Arapitsas et al. 2008).

The potential of okra (Abelmoschus esculentu L) as antidiabetic has been demonstrated from some research. Antidiabetic potential of okra by following mechanism: improve uptake

"Corresponding Author: Tel: +6282311911134 email: putripuncakanjani@gmail.com 
glucose tissue (Prior et al. 2008), improve insulin sensitivity (Sasaki et al. 2007), prevent lipid peroxidation (Oboh et al. 2014), promote liver and pancreatic cell proliferation and act as $\alpha$-glucosidase inhibitor (Babu et al. 2013). Research conducted by Sabitha et al. (2013) have shown that administration of peel and seed okra extract with th dosage of 100 and $200 \mathrm{mg} / \mathrm{kgBB}$ significantly lowered in blood glucose levels and increase weight loss and prevent lipid peroxidation in STZ-induced diabetic rats. Purple okra as a results of okra superior cultivation from Zahira varieties. Some scientists studied green okra useful in DM and some of them having antioxidant properties, while are studying purple okra useful still rarely done. Antioxidant potential of green okra and purple okra need to be intervention for DM treatment. The aim of the present study was analyzed the effect of green and purple okra extract as anti hyperglycemia agents and improve the level of MDA liver in streptozotocin (STZ) induced diabetic rats.

\section{METHODS}

\section{Design, location, and time}

Pre and post test controlled group design were used for the experiment. This research held on February until September 2017. It took place in Food Chemistry and Nutrient Analysis Laboratory Community, Nutrition Department, Faculty of Human Ecology and SEAFAST Center Bogor Aglicultural University. In vivo stage were done at Animal Laboratory Management Unit (UPHL) Faculty of Veterinary IPB. MDA liver measurement were conducted at Pathology Anatomy Laboratory, Medical Faculty in Brawijaya University Malang. This research were got ethical cleareance from Animal Ethical Comittion LPPM IPB with number 63-2017 IPB.

\section{Materials and tools}

The main material used in this research is green okra from Naila varieties and purple okra from Zahira varieties was obtained from Prof. Muhammad Syukur Department of Agronomy and Horticulture of Bogor Agricultural University. 3 month old male Sprague Dawley rats obtained from the National Food and Drug Administration Center BPOM Jakarta. Material used in the okra extraction is $70 \%$ methanol solution. Materials used for proximate analysis include 0.3 $\mathrm{ml}$ Folin-Ciocaiteu, gallic acid standard solution for total phenolic analysis and quercetin standard solution for quercetin analysis. Equipments used in the making of okra extraction and proximate analysis were magnetic stirer Bellco glass. inc (Vineland, USA), vacuum evaporator, freeze dryer, and spectrophotometry Optima SP-300 (Japan), glass (Pyrex $\left.{ }^{\circledR}\right)$, filter paper Whatman, micropipet $1000 \mu \mathrm{L}$ and $10-100 \mu \mathrm{L}$, reaction tube (Schott Duran), centrifuge (Kokusan, Japan), column stationary phase HPLC, vortex, and water bath aquades (Julabo SW22, Japan).

Material and equipment for animal maintenance were individual cage with cage area 33.5 x 27 x $12 \mathrm{~cm}$, husk, drink bottle $250 \mathrm{ml}$, digital scales Sigma, rats fed standard based on AIN-93 formulation. Material and equipment for diabetes induction were streptozotocin (STZ) from Sigma Chemical Co. (St. Louis, MO, USA), physiological $\mathrm{NaCl}$ and syringe intraperitoneal injection (Terumo). Blood glucose were measured using glucometer (GlucoDr Korea) and glucostrip (GlucoDr Korea). Malondialdehyde (MDA) were analyzed using ketamine and xylazin mix solution, scalpel, surgical board for got liver organ.

\section{Procedures}

Okra extraction and preparation. $500 \mathrm{~g}$ green and purple okra (without separating between skin and seeds) were dried using freeze dryer vertical tipe Snijders scientific. Dried okra weighed and smoothed with blender. $10 \mathrm{~g}$ powder dried okra added with $500 \mathrm{ml} 70 \%$ methanol solution in the Erlenmeyer continued with extraction gradually until obtained clearly residue. Filtrate evaporated with vacum evaporator. Okra extract weighed and analyzed bioactive compound total phenolic using spectrophotometry method (Liao et al. 2012) and quercetin compound analyzed using High Perfomance Liquid Chromatography (HPLC) method.

Quercetin analysis using HPLC method. $0.5 \mathrm{~g}$ sample were diluted with $\mathrm{MeOH} 62.5 \%$ TBHQ ( $2 \mathrm{~g} / \mathrm{l})$ up to $20 \mathrm{ml}$. Sample solution were incorporated in Erlenmeyer added with $5 \mathrm{ml} \mathrm{HCl}$ $6 \mathrm{M}$ then refluxed for 2 hours at $90^{\circ} \mathrm{C}$. The extract were allowed to cool then filtered into 25 $\mathrm{ml}$ measuring flask. A filtering were performed using $0.45 \mu \mathrm{m}$ filter paper whatman and were placed into $25 \mathrm{ml}$ measuring flask diluted with aquades. $10 \mu \mathrm{L}$ samples were injected into HPLC $370 \mathrm{~nm}$ with comparison of $\mathrm{ACN}$ and $\mathrm{K}_{2} \mathrm{HPO}_{4}$ $0.025 \mathrm{M}$ column phase $25: 75$. Standard quercetin curve were read for $30 \mathrm{~min}$, followed by injecting 
$10 \mu 1$ samples into HPLC system for $30 \mathrm{~min}$ to obtain quercetin levels of okra extract (Hertog et al. 1995).

Streptozotocin (STZ) induction and rats maintenance. 24 rats were adapted for 14 days with standard feeding formulated based on AIN93 and allowed to drink water ad libitum. At day 15 after adaptation, 4 rats were included in normal group $(\mathrm{N})$ and 20 rats were performed intraperitoneal STZ induction. After overnight fasting $(12-16 \mathrm{~h})$, rats were injected intraperotoneally with single dose of STZ $50 \mathrm{mg} / \mathrm{kgBW}$. The success of diabetes induction was determined by measuring blood glucose levels after a 3-day STZ induction. When fasting glucose plasma (FPG) levels $>126 \mathrm{mg} / \mathrm{dl}$ were included in diabetic model rats groups (Jung et al. 2011). The diabetic model rats were divided into 5 randomized treatment groups including diabetes control (DM) ie untreated diabetic model rat, treatment group given green okra extract with the dosage of $5 \mathrm{mg} / \mathrm{kgBW}$ quercetin (GOE I) and $10 \mathrm{mg} / \mathrm{kgBW}$ (GOE II ), treatment group given purple okra extract with the dosage of $5 \mathrm{mg} / \mathrm{kgBW}$ quercetin (POE I) and $10 \mathrm{mg} / \mathrm{kgBW}$ (POE II). The GOE and POE dissolved with Twin $1 \%$ were administered orally to the treatment group animals for 14 days. Administration of okra extract each day limited to maximum of $3.5 \mathrm{ml}$ based on stomach capacity of rats were $10 \mathrm{ml} / \mathrm{kgBW}$ (Mc Connel et al. 2008). The dosage of $5 \mathrm{mg} / \mathrm{kgBW}$ quercetin on okra extract equals with consumption of 263 $\mathrm{g}$ fresh okra for humans $70 \mathrm{~kg}$, while the dosage of $10 \mathrm{mg} / \mathrm{kgBB}$ quercetin on okra extract was equivalent to the consumption of $526 \mathrm{~g}$ resh okra. The dosage of okra extract was based on quercetin compound present in okra based on Gomes et al. (2015) research.

Measurement of fasting plasma glucose (FPG) and malondialdehyde of liver levels. Blood glucose was measured every five days start from 0 day after rats showed diabetic condition by induced STZ. After overnight fasting (rats were deprived of food for 12-16 h but allowed to water), rats were collected blood from vein tail. In the end of intervention (day 15) rats were general anesthesia using ketamine: $75 \mathrm{mg} /$ $\mathrm{kgBB}$ and xylazine: $5 \mathrm{mg} / \mathrm{kgBB}$ sollution. Liver organ were abtained from rats surgery. Measurement of malondialdehyde level on liver organ using thiobarbiturat acid test (TBA) (Aulanni' am et al. 2012).

\section{Data analysis}

Data was processed and analyzed using Microsoft Excel 2010 and SPSS software version 16.0. Statistical analysis were assessed by one-way analyses of variance (ANOVA). Pretest and post-test data of results were assessed by paired sample t-test to analyzed differences data between before and after intervention. If there is differences between data sets (significant on $\mathrm{p}<0.05$ ), further test conducted by Duncan's multiple-range test.

\section{RESULTS AND DISCUSSION}

\section{Bioactive compound of green okra and purple okra extract.}

Initial stages in this study is to analyze bioactive compound of green okra extract (GOE) and purple okra extract (POE) including total phenolic, and quercetin. GOE contents quercetin compound $0.27 \mathrm{mg} / \mathrm{g}$, while quercetin compound of POE were higher $0.45 \mathrm{mg} / \mathrm{g}$ (Table 1). Quercetin is the major flavonoid in Okra where $70 \%$ total antioxidant compound in okra comes due to the quercetin derivative (Shui \& Peng 2004). Quercetin content in GOE and POE were higher when compared with torbangun leaves extract (Coleus amboinicus Lour) $0.02 \mathrm{mg} / \mathrm{g}$ (Trini et al. 2015).

Table 1. Bioactive compound of GOE and POE

\begin{tabular}{ccc}
\hline Bioactive compound & GOE & POE \\
\hline Total Phenolic $(\%)$ & 3.58 & 3.60 \\
Quercetin $(\mathrm{mg} / \mathrm{g})$ & 0.27 & 0.45 \\
\hline
\end{tabular}

Scientific research about bioactive content of okra extract has been done. Some studies have shown that the skin and okra seeds contain polyphenol components such as hydroxynamic acid and its derivatives, catechins, quercetin derivatives, and flavonols (Shui \& Peng 2004; Huang et al. 2007). The results showed that total phenolic of POE and GOE are similar almost, while quercetin on POE was higher than GOE. Okra skin contains polyphenols from hydroxynamic acid group and quercetin derivatives in the amount of $0.2 \mathrm{mg} / \mathrm{g}$ and $0.3 \mathrm{mg} / \mathrm{g}$ samples respectively (Arapitsas et al. 2008). In this study using fresh okra without separated between skin and seeds. 
The highest polyphenols compound in okra can found in seeds with total phenolic of $29.5 \%$, while in skin $1.25 \%$ (Fan et al. 2014). $\alpha$-glucosidase activity in okra leaf extract and okra seed is quite large $\left(\mathrm{IC}_{50}=142.69 \mu \mathrm{g} / \mathrm{ml} ; 150.47 \mu \mathrm{g} / \mathrm{ml}\right)$, while $\alpha$-amylase activity $\left(\mathrm{IC}_{50}=132.63 \mu \mathrm{g} / \mathrm{ml} ; 147.23\right.$ $\mu \mathrm{g} / \mathrm{ml}$ ) (Sabitha et al. 2012). $\alpha$-glucosidase and $\alpha$-amylase activity using $\mathrm{IC}_{50}$ method defined as the ability of okra extract to inhibit $50 \%$ breakdown of carbohydrates into glucose, this activity plays important role in the antidiabetic mechanism in managing increased blood glucose.

\section{Effect of okra extract intervention on blood glucose}

The mean fasting plasma glucose (FPG) of treatment group at pre-intervention were 210.25 to $285 \mathrm{mg} / \mathrm{dl}, 14$ days after oral administration of okra extract (green and purple) FPG ranged from 100.25 to $125.25 \mathrm{mg} / \mathrm{dl}$ (Table 2). 14-days after POE treatment, significantly decreased the FPG in diabetic rats $(p<0.05)$. GOE treatment group also showed a decrease in FPG comparable amount to the normal range although not significant based on different Paired t-test. From preliminary test results of okra extract known quercetin in POE was higher than GOE. The major flavonoid in okra is quercetin showed act as an antidiabetic potency (Fan et al. 2014).

Flavonoids have done antioxidant activity by scavenging ROS (Reactive Oxygen Species) and RNS (Reactive Nitrogen Species) resulting from diabetogenic compounds ie STZ (Fuhrman $\&$ Aviram 2001). The major polyphenolic groups of flavonoids, tannins and phenolic acids play a role in carbohydrate metabolism by inhibition of $\alpha$-glucosidase and $\alpha$-amylase responsible for digestion of starch into glucose, leading to an increased the blood glucose (Iwai 2008: Tadera et al. 2006) . Decrease in FPG on treatment group of okra extract (green or purple) due to quercetin compound in okra showed antioxidant activity by reduction free radicals from STZ. When free radicals can be scavenge will cause the insulin receptors in beta cells become active and were effectively made glucose can be used by cells as energy and cause decreased gluconeogenesis, as a result FPG levels go through decrease. Regulation of carbohydrate metabolism by polyphenolics is also due to an increase of glycolysis and glucose oxidation in the body that can improve glucose homeostasis and insulin resistance (Bahadoran et al. 2013).

In vitro studies showed that polyphenolic quercetin may increase insulin production, glucose availability in muscle cells and adipocytes through GLUT4 glucose transporter translocation to plasma membranes thus inducing the AMP-activated protein kinase (AMPK) pathway (Zhang et al. 2011; Park et al. 2007 ). AMPK is an energy cellular sensor as a stimulation of glucose uptake to increase of glucose uptake as an energy store, when AMPK pathway become active is considered a new mechanism in the role of treatment of obesity, type $2 \mathrm{DM}$, metabolic syndrome (Towler 2007).

POE group with the dosage of $5 \mathrm{mg} /$ $\mathrm{kgBW}$ quercetin showed that greatest effect on decreases of FPG compared with other treatment groups. The increasing dosage of okra extract

Table 2. Fasting plasma glucose (FPG) in rats pre and post intervention

\begin{tabular}{cccccc}
\hline \multirow{2}{*}{ Groups } & $\begin{array}{c}\text { FPG } \\
\text { pre intervention }\end{array}$ & $\begin{array}{c}\text { FPG } \\
\text { post intervention }\end{array}$ & $\mathrm{p}$ & \multirow{2}{*}{$\Delta$ FPG } \\
\cline { 2 - 3 } & Mean \pm SEM $(\mathrm{mg} / \mathrm{dl})$ & Mean \pm SEM $(\mathrm{mg} / \mathrm{dl})$ & & \\
\hline Normal & $84.25 \pm 5 .$. & $82.75 \pm 5.39$ & & 0.678 & $-1.50 \pm 3.28$ \\
DM & $319.00 \pm 71.04^{\mathrm{a}}$ & $375.00 \pm 70.60^{\mathrm{b}}$ & & 0.316 & $54.25 \pm 47.95^{\mathrm{b}}$ \\
GOE I & $215.50 \pm 50.34^{\mathrm{a}}$ & $100.25 \pm 8.32^{\mathrm{a}}$ & & 0.074 & $-115.25 \pm 42.86^{\mathrm{a}}$ \\
GOE II & $210.25 \pm 32.13^{\mathrm{a}}$ & $124.25 \pm 34.26^{\mathrm{a}}$ & & 0.061 & $-86.00 \pm 29.45^{\mathrm{a}}$ \\
POE I & $284.50 \pm 50.77^{\mathrm{a}}$ & $103.75 \pm 7.09^{\mathrm{a}}$ & & $0.029^{*}$ & $-180.75 \pm 45.65^{\mathrm{a}}$ \\
POE II & $236.00 \pm 71,89^{\mathrm{a}}$ & $145.00 \pm 58.43^{\mathrm{a}}$ & & $0.009^{*}$ & $-91 \pm 14.80^{\mathrm{a}}$ \\
p & $0.0084^{* *}$ & $0.002^{* *}$ & & $0.009^{* *}$ \\
\hline
\end{tabular}

*) Differences test using Paired t-test, significant difference on $\left.\mathrm{p}<0.05,{ }^{* *}\right)$ ANOVA followed by Duncan's multiple range test, significant on $\mathrm{p}<0.05$. 
didn't showed better effect on blood glucose levels because of administration high dosage of certain bioactive compounds such as flavonoids can be prooxidant and trigger an increase in ROS by autoresidation and altering redox reactions (Bouayed \& Bohn 2010; Iwasaki et al. 2011). All of the treatment group had a significant decreases of FPG compared with DM group, but the decrease of FPG between treatment groups was not significantly different or relatively similar and close to FPG range in normal group. The decrease of FPG levels with administration of okra extract was due to quercetin compound in okra. Oral administration of quercetin in STZ-induced diabetic rats has an effect decreasing in serum glucose and viability of pancreatic $\beta$ cells by increasing the natural antioxidant system and inhibition of lipid peroxidation (Yin et al. 2011).

\section{Effect of okra extract intervention on malon- dialdehyde of liver}

In this study different interventions showed that significant changes $(\mathrm{p}<0.05)$ on MDA levels rats. MDA levels after 14 days of treatment in DM group were significantly different with mean MDA levels of normal and treatment groups (Table 3).

Table 3. Malondialdehyde (MDA) of liver level on post intervention

\begin{tabular}{cc}
\hline Groups & $\begin{array}{c}\text { Malondialdehyde (MDA) level } \\
\text { Mean } \pm \text { SEM }(\mathrm{ng} / \mathrm{ml})\end{array}$ \\
\hline Normal & $148.00 \pm 2.22$ \\
DM & $227.25 \pm 3.07^{\mathrm{c}}$ \\
GOE I & $164.50 \pm 8.87^{\mathrm{ab}}$ \\
GOE II & $186.88 \pm 10.04^{\mathrm{b}}$ \\
POE I & $156.50 \pm 10.05^{\mathrm{a}}$ \\
POE II & $182.00 \pm 7.41^{\mathrm{ab}}$ \\
$\mathrm{p}$ & $0.000^{*}$ \\
* ANOVA followed by Duncan's multiple range test, signifi- \\
cant (p<0.05)
\end{tabular}

High levels of MDA in DM control due to the condition of diabetes caused insulin levels low as a result of $\beta$-oxidation initiation fatty acids and the accumulation of free radicals in body that produce lipid peroxidation products (Annie et al. 2005). The mean levels of MDA in treatment group showed significant improvement af- ter 14 days the intervention compared to a control group of diabetes, shown that okra extract based on quercetin compound reduced level of MDA in STZ induced diabetic rats. Antioxidant activity on the major flavonoid in okra that is quercetin compound due to an aromatic hydroxyl group which as ROS and RNS scavenger by inhibiting peroxidation reaction which leads to formation of final products in lipids peroxidation (du Thie \& Crozier 2000; Moskaug et al. 2004).

Polyphenols compounds have antioxidant activity as free radical scavenger by direct interaction with cellular receptors as a key of redox stages resulting in modified redox reactions and triggering a series of redox-dependent reactions (Scalbert et al. 2005). In vivo studies conducted by Oboh et al. (2014) reported that quercetin significantly inhibited the activity of $\alpha$-amylase and $\alpha$-glucosidase which suppressed the rise of blood glucose thus inhibiting lipid peroxidation process and pancreatic cell destruction.

The mean data of MDA levels showed that group receiving GOE or POE intervention with the dosage of $5 \mathrm{mg} / \mathrm{kgBW}$ caused the change of MDA level close to the range MDA levels of normal group. The mean level of MDA in GOE and POE treatment group with the dosage of 10 $\mathrm{mg} / \mathrm{kgBW}$ was significantly different with mean level of MDA in DM group, but the change of MDA level given better effect compared with the dosage of $5 \mathrm{mg} / \mathrm{kgBW}$.

Intervention of POE based on quercetin compound at the dosage of $5 \mathrm{mg} / \mathrm{kgBW}$ shows that highest decrease level of MDA compared with other treatment groups after 14 days. Quercetin treatment could act as antioxidant and prooxidant depending on the concentration given. At low concentrations of quercetin given protective effect on DNA damage (in vitro) in human lymphocytes and prevent occurrence of stress oxidative, but high concentration of quercetin with the dosage of $30 \mu \mathrm{M}$ caused cytotoxicity effect (Spencer et al. 2003; Wilms et al. 2005).

\section{CONCLUSION}

Intervention of okra extract (green okra and purple okra) based on quercetin compound showed reduction on blood glucose levels and improved level of MDA liver. Purple okra extract significantly lowered blood glucose in streptozotocin induced diabetic rats. 
Further research is needed on influence the dosage of okra extract based on quercetin compound in a variety of levels from low dosage up to high dosage (more than $10 \mathrm{mg} / \mathrm{kgBW}$ ) to know the effects and characters of anti/prooxidants quercetin of okra.

\section{ACKNOWLEDGEMENTS}

Authors wishing to acknowledge financial support from Prof. Dr. Muhamad Syukur, SP, M.Si Agronomi and Holticulture Department, Bogor Agricultural University for this research.

\section{REFERENCES}

Aguirre L, Arias N, Macarulla MT, Gracia A, Portillo MP. 2011. Benefical effects of quercetin on obesity and diabetes. Nutraceuticals J 4(1):189-198.

[ADA] American Diabetes Association. 2014. Diagnosis and classification of diabetes mellitus. Diabetes Care 37(1):S81-S89.

Annie SK, Rajendran I, Punitha SR. 2005. Antidiabetic activity of alcoholic stem extract of Coscinium fenestratum in streptozotocin-nicotinamide induced type 2 diabetic rats. J Ethnopharmacol 97(2):369-374.

Aouacheri O, Saka S, Krim M, Messadia A, Maidi I. 2014. The investigation of the oxidative stress-related parameters in type 2 diabetes mellitus. Can J Diabetes 03(2):1-6.

Arapitsas P. 2008. Identification and quantification of polyphenolic compounds from okra seeds and skins. Food Chem 110(4):10411045.

Aulanni'am R. Anna, Rahmah NL. The potency of sargassum duplicatum bory extract on inflammatory bowel disease therapy in rattus norvegicus. 2012. Journal of Life Sciences 6(2):144-154.

Babu PV, Liu D, Gilbert ER.2013. Recent advances in understanding the anti-diabetic actions of dietary flavonoids. J Nutr Biochem 24(11):1777-1789.

Bahadoran Z, Mirmiran P, Azizi F. 2013. Dietary polyphenols as potential nutraceuticals in management of diabetes: a review. J Diabetes Metab Disord 12(43):1-9.

Bouayed J, Bohn T. 2010. Exogenous antioxidants-Double-edged swords in cellular redox state: Health beneficial effects at physiologic doses versus deleterious effects at high doses. Oxid Med Cell Longev 3(4): 228-237.

Damayanthi E, Kusumorini N, Kustiyah L, Pontjo B, Rimbawan, Bait Y, Ritonga D, Suprihatini R, Hypoglicemic Activity of Black Tea as good a Green Tea but better than Mulberry Leaf Tea on Diabetic Rats. inside Mao Z, He Q, Xiao H, editor. Global Health Conference Proceedings. presented in : Asia Pacific Academic Consortium for Public Health (APACPH), The $45^{\text {th }}$ Annual Conference 2013 Oct 24-27. Wuhan, China. Wuhan 223.

du Thie G, Crozier A. 2000. Plant derived phenolic antioxidants. Clin Nutr Metab 11(1):4347.

Fan S, Guo L, Zhang Y, Sun Q, Yang B, Huang C. 2014. Extract of okra lowers blood glucose and serum lipids in high fat diet-induced obese C57BL/6 mice. J Nutr Biochem 25(7):702-709.

Fuhrman B, Aviram M. 2001. Flavonoids protect LD1 from oxidation and attenuate atherosclerosis. Curr Opin Lipidol 12(1):41-48.

Gomes IB, Porto Ml, Santos MC, Campagnaro BP, Gava LA, Pereira TM, Meyrelles SS, Vasquez SC. 2015. The protective effect of oral low-dose kuersetin on diabetic nephropathy in hypercholesterolemic mice. Front Physiol 34(7):236-247.

Gupta S, Aziz N, Sekhon L, Agarwal R, Mansour G, Li J, Agarwal A. 2009. Lipid peroxidation and antioxidant status in preeclampsia, a systematic review. Obstet Gynecol Surv 64(11):750-759.

Hertog MGL et al. 1995. Flavonoid intake and long-term risk of coronary heart disease and cancer in the seven countries study. Arch Int Med 155(4):381-386.

Huang Z, Wang B, Eaves DH, Shikany JM, Pace RD. 2007. Phenolic compound profile of selected vegetables frequently consumed by African Americans in iwthe southeast United States. Food Chem 103(4):13951402.

[IDF] International Diabetes Federation. 2013. IDF diabetes atlas. 6th edition. Brussels, Belgium: International Diabetes Federation.

Iwai K. 2008. Antidiabetic and antioxidant effects of polyphenols in brown alga Eck- 
lonia stolonifera in genetically diabetic KK-A(y) mice. Plant Foods Hum Nutr 63(4):163-169.

Iwasaki Y, Hirasawa T, Maruyama Y, Ishii Y, Ito R, Saito K, Umemura T, Nishikawa A, Nakazawa H. 2011. Effect of interaction between phenolic compounds and copper ion on antioxidant and pro-oxidant activities. Toxicology in Vitro 25(7):1320-1327.

Jung JY, Lim Y Moon MS, Kim JY, Kwon O.2011. Onion peel extract ameliorate hyperglycemia and insulin resistance in high fat diet/streptozotocin-induced diabetic rats. Nutr Metab 18(8):1-8.

[Kemenkes RI] Kementrian Kesehatan Republik Indonesia. 2013. Riset Kesehatan Dasar Tahun 2013. Jakarta: Kemenkes RI.

Liao H, Liu H, Yuan K. 2012. A new flavonol glycoside from the Abelmoschus esculentus Linn. Pharmacognosy Magazine 8(29):12-15.

Moskaug J, Carlsen H, Myhrstad M, Blomhoff R. 2004. Molecular imaging of the biological effect of quercetin and quercetin-rich foods. Mech Ageing Dev 125(4):315-324.

Oboh G, Ademosun AO, Ayeni PO, Omojokun OS, Bello F. 2014. Comparative effect of kuersetin and rutin on $\alpha$-amylase, $\alpha$-glucosidase, and some pro-oxidant-induced lipid peroxidation in rat pancreas. Comp Clin Pathol 24(1):1-8.

Park CE, Kim MJ, Lee JH, Min BI, Bae H, Choe W. 2007. Resveratrol stimulates glucose transport in $\mathrm{C} 2 \mathrm{C} 12$ myotubes by activating AMP-activated protein kinase. Mol Med 39(2):222-229.

Prior RL, Wu X, Gu L, Hager TJ. 2008. Whole berries versus berry anthocyanins: interactions with dietary fat kadars in the C57BL/6J mouse model of obesity. J Agric Food Chem 56(3):647-653.

Sabitha V, Panneerselvam K, Ramachandran S. 2012. In vitro $\alpha$-glucosidase dan $\alpha$-amylase enzyme inhibitory effects in aqueous extracts of Abelmoschus esculentus (L.) Moench. Asian Pacific J Tropical Biomedicine 2(1):S162-S164.

Sabitha V, Ramachandran S, Naveen KR, Panneerselvam K. 2013. Antidiabetic and antihyperlipidemic potential of Abelmoschus esculentus (L.) Moench. In streptozotocininduced diabetic rats. J Pharm Bioallied Sci 3(3):397-402.
Sasaki R, Nishimura N, Hoshino H, Isa Y. 2007. Cyanidin 3-glucoside ameliorates hyperglycemia and insulin sensitivity due to downregulation of retinol binding protein 4 expression in diabetic mice. Biochem Pharmacol 74(11):1619-1627.

Scalbert A, Johnson IT, Saltmarsh M. 2005. Polyphenols: antioxidants and beyond. Am J Clin Nutr 81(1):215S-217S.

Shui G, Peng LL. 2004. An improved method for analysis of major antioxidant of Hibiscus escelntus Linn. J Chromatograhy A 104(1):17-24.

Spencer J, Kuhnle G, Williams R, Rice-Evans C. 2003. Intracellular metabolism and bioactivity of quercetin and its in vivo metabolites. Biochem J 372(1):173-181.

Tadera K, Minami Y, Takamatsu K, Matsuoka T. 2006. Inhibition of alphaglucosidase and alpha-amylase by flavonoids. J Nutr Sci Vitaminol 52(2):149-153.

Tangvarasittichai S. 2015. Oxidative stress and T2DM. World J Diabetes 6(3):456-480.

Towler MC, Hardie DG. 2007. AMP-activated protein kinase in metabolic control and insulin signaling. Circ Res 100(3):328-341.

Trini S, Rimbawan, Damanik R, Bintang M, Handharyani E. 2015. Efek Ekstrak Daun Torbangun (Coleus amboinicus Lour) Sebagai Antioksidan Pada Hati Tikus Diabetes. Prosiding Seminar Ilmiah Perhimpunan Biokimia \& Biologi Molekuler Indonesia (PBBMI) 63-68.

Wedick NM, Pan A, Cassidy A, Rimm EB, Sampson L, Rosner B. 2012. Dietary flavonoid intakes and risk of type 2 diabetes in US men and women. Am J Clin Nutr 105(5):925-933.

Wein S, Behm N, Petersen RK. 2010. Quercetin enhances adiponectin secretion by a PPAR Gamma independent mechanism. Eur J Pharm Sci 41(1):16-22.

Wilms LC, Hollman PC, Boots AW, Kleinjans JC. 2005. Protection by quercetin and quercetin-rich fruit juice against induction of oxidative DNA damage and formation of BPDE-DNA adducts in human lymphocytes. Mutat Res/Genetic Toxicol Environ Mutagen 582(1):155-162.

Xiao ZP, Peng ZY, Peng MJ, Yan WB, Ouyang YZ, Zhu HL. 2011. Flavonoids health benefits and their molecular mechanism. Mini Rev Med Chem 11(2):169-177. 
Anjani et al.

Yin P, Zhao S, Chen S, Liu J, Shi L, Wang X, Liu Y, Ma C. 2011. Hypoglycemic and hypolipidemic effects of polyphenols from burs of Castanea mollissima Blume. Molecules 16(10):9764-9774.
Zhang B, Kang M, Xie Q, Xu B, Sun C, Chen K, Wu Y. 2011. Anthocyanins from Chinese bayberry extract protect $\beta$ cells from oxidative stress-mediated injury via HO-1 upregulation. J Agric Food Chem 59(2):537545. 